NOTE

\title{
Ribosomal RNA gene sequences confirm that protistan endoparasite of larval cod Gadus morhua is Ichthyodinium sp.
}

\author{
Alf Skovgaard ${ }^{1, *}$, Stefan Meyer ${ }^{2}$, Julia Lynne Overton ${ }^{3}$, Josianne Støttrup ${ }^{3}$, \\ Kurt Buchmann $^{1}$ \\ ${ }^{1}$ Section of Fish Diseases, Department of Veterinary Disease Biology, University of Copenhagen, Stigbøjlen 7, \\ 1870 Frederiksberg, Denmark \\ ${ }^{2}$ Institute for Hydrobiology and Fisheries Science, University of Hamburg, Olbersweg 24, 22767 Hamburg, Germany \\ ${ }^{3}$ Section for Coastal Ecology, National Institute of Aquatic Resources, Technical University of Denmark, Jœgersborg Alle 1,
} 2920 Charlottenlund, Denkmark

\begin{abstract}
An enigmatic protistan endoparasite found in eggs and larvae of cod Gadus morhua and turbot Psetta maxima was isolated from Baltic cod larvae, and DNA was extracted for sequencing of the parasite's small subunit ribosomal RNA (SSU rRNA) gene. The endoparasite has previously been suggested to be related to Ichthyodinium chabelardi, a dinoflagellate-like protist that parasitizes yolk sacs of embryos and larvae of a variety of fish species. Comparison of a $1535 \mathrm{bp}$ long fragment of the SSU rRNA gene of the cod endoparasite showed absolute identity with $I$. chabelardi, demonstrating that the 2 parasites are very closely related, if not identical. This finding is discussed in relation to some morphological differences that appear to exist between $I$. chabelardi and the cod endoparasite.
\end{abstract}

KEY WORDS: Fish egg · Yolk sac parasite $\cdot$ Endoparasite $\cdot$ Gadus morhua $\cdot$ Ichthyodinium

Resale or republication not permitted without written consent of the publisher

\section{INTRODUCTION}

Eggs and larvae of Atlantic cod Gadua morhua from the Baltic Sea are hosts to a protistan endoparasite that is located in the yolk sac of embryos and newly hatched larvae (Buchmann et al. 1993). Prevalence of the protistan endoparasite was as high as 25 to $88 \%$ in eggs from wild cod caught in Danish waters (Buchmann et al. 1993, Pedersen et al. 1993, Pedersen \& Køie 1994), and the parasite is, therefore, thought to be of significant ecological importance. Mortality caused by infection of this parasite has not been investigated in much detail, but infection has been suggested to be lethal (Pedersen 1993) since the parasite seems to be associated with elevated mortality (Pedersen \& Køie 1994). An indistinguishable protistan parasite exists in embryos and larvae of turbot Psetta maxima (as Scophthalmus maximus; Pedersen 1993) from the western part of the Baltic Sea. Eggs of Atlantic cod and turbot are buoyant (i.e. pelagic). The demersal eggs of herring Clupea harengus in the Baltic Sea, on the other hand, are not susceptible to infection by this parasite (Pedersen \& Køie 1994).

The protistan endoparasite of cod and turbot can typically be detected as large spheres (25 to $80 \mu \mathrm{m})$ in the yolk sac of embryos (Pedersen 1993, Pedersen et al. 1993). Mononucleate stages are spherical with a smooth surface, whereas larger, multinucleate plasmodia have more irregular surfaces. The larger, multinucleate stages are thought to produce smaller mononucleate cells through budding, but the actual development of parasite stages has not been investigated (Pedersen 1993). The parasites seem to disappear from the yolk sac before the end of the yolk sac stage, presumably because parasite cells enter the vascular system and/or the tissue of the larvae (Pedersen 
1993, Pedersen et al. 1993). It is, however, also possible that the disappearance of the parasite is a result of elevated mortality among infected larvae (Pedersen 1993). When the protistan endoparasite of cod and turbot was first discovered, a similarity to the dinoflagellate-like parasite of marine fish eggs Ichthyodinium chabelardi was noted (Buchmann et al. 1993, Pedersen et al. 1993, Pedersen \& Køie 1994). It was also clear from the beginning, on the other hand, that the protistan endoparasite was not identical to $I$. chabelardi in all respects. In particular, the aggressiveness of the infection and the development of the parasite appeared unlike that of I. chabelardi. I. chabelardi was first described infecting eggs of sardine Sardina pilchardus in the Bay of Algiers in the Mediterranean Sea (Hollande \& Cachon 1952, 1953), and it is the only other protist known to parasitize yolk sacs of marine fish embryos and larvae. Since the 1952/1953 studies many other fish species have been reported as hosts for Ichthyodinium spp. Among these are species that are important for human consumption in Europe, e.g. mackerel Scomber scombrus (Meneses et al. 2003), gilthead seabream Sparus aurata (Marinaro 1971), and in southeast Asia, e.g. yellowfin tuna Thunnus albacares (Yuasa et al. 2007) and leopard coral grouper Plectropomus leopardus (Mori et al 2007). A recent study showed that European and Asian isolates of Ichthyodinium spp. represent 2 different phylotypes (Skovgaard et al. 2009). Despite the ubiquitous occurrence of $I$. chabelardi, its life cycle and route of infection are still not completely understood. Recent data indicate that free-swimming $I$. chabelardi cells infect fish eggs after spawning (Mori et al. 2007, Yuasa et al. 2007), but it was previously suggested that the protistan endoparasite of cod and turbot is transferred vertically through the fish gametes (Pedersen \& Køie 1994).

The morphology and ultrastructure of the endoparasite of cod have been relatively well studied, but the organism exhibits only few characteristic morphological traits, and none of these are sufficient for an exact classification of the organism. It has, therefore, not been possible to confirm or disprove a possible close similarity to Ichthyodinium chabelardi. The main ultrastructural findings have so far been that the endoparasite of cod possesses mitochondria with tubular cristae, signifying that it is of protistan nature (Pedersen et al. 1993, Pedersen \& Køie 1994). No production of flagellated swarmer cells has been observed for the endoparasite of cod and turbot, and the parasite has neither chloroplast nor trichocysts. Another ultrastructural study confirmed these findings and reported on different cell types of this parasite (Bloch et al. 1997). Interestingly, Pedersen \& Køie (1994) found that eggs became infected after having been incubated in sterilized seawater and, therefore, concluded that the para- site was transmitted via the fish gametes. Since characteristic morphological and ultrastructural traits have not been sufficient for classification of the protistan endoparasite, we seek here to determine the identity of the enigmatic, protistan parasite of cod embryos and larvae by sequencing its small subunit ribosomal RNA (SSU rRNA) gene.

\section{MATERIALS AND METHODS}

Sampling. Eggs of cod Gadus morhua were sampled during June 2007 for assessment of endoparasites. Broodstock fish had previously been collected from the Baltic Sea in order to produce first-feeding cod larvae for restocking purposes (Støttrup et al. 2008) and were kept at Bornholm's Salmon Hatchery in Nexø on the island of Bornholm, Denmark. Broodstock fish were treated with $80 \mathrm{mg} \mathrm{l}^{-1}$ formalin for $1 \mathrm{~h}$ to remove external parasites before being transferred to holding tanks, and the fish were allowed to spawn in the tank freely. Temperature in holding tanks was $7^{\circ} \mathrm{C}$ and the salinity was 16 psu. Infected eggs were identified and isolated by means of a stereomicroscope (Wild Heerbrugg), and parasites were photographed with a Leica DFC290 camera. Parasites were then removed by dissection, and parasite cells were placed in Eppendorf tubes containing $2 \mathrm{ml}$ of $1 \% \mathrm{~N}$-cetyl N,N,N-trimethylammonium bromide (CTAB) extraction buffer. Samples were frozen immediately and kept at $-20^{\circ} \mathrm{C}$ until processing.

DNA extraction. Extraction of DNA was done by physical cell rupture, followed by a standard CTAB protocol. First, parasite cell mass was isolated from 1 to 2 recently hatched larvae and placed in $1 \mathrm{ml} \mathrm{CTAB}$ in Eppendorf tubes. The tubes then received approximately $500 \mathrm{mg}$ of $100 \mu \mathrm{m}$ zirconia-silica beads (Biospec Products) and were mixed for $2 \times 1 \mathrm{~min}$ at $30 \mathrm{~Hz}$ in a Retsch Qiagen TissueLyser (Retsch). DNA was extracted further with chloroform, precipitated in $-20^{\circ} \mathrm{C}$ isopropanol, and washed with $-20^{\circ} \mathrm{C} 70 \%$ ethanol. Finally, DNA was re-suspended in $30 \mu \mathrm{l}$ of sterile water and stored at $-20^{\circ} \mathrm{C}$.

PCR. DNA was PCR-amplified in 2 steps: a standard PCR with general primers followed by a nested PCR with specific primers. The standard PCR was performed using general eukaryotic primers EukA and EukB (Medlin et al. 1988). The $50 \mu \mathrm{l}$ PCR mixture contained 2 to $5 \mu \mathrm{l}$ DNA extract as template, $200 \mu \mathrm{M}$ of each dNTP, $1.5 \mathrm{mM} \mathrm{MgCl}_{2}, 0.5 \mu \mathrm{M}$ of each primer, 1 unit of Taq polymerase, and the PCR buffer supplied with the enzyme (Promega). The PCR was run in an automated thermocycler (MJ Mini cycler, Bio-Rad Laboratories) under the following conditions: an initial denaturing step at $94^{\circ} \mathrm{C}$ for $1 \mathrm{~min}$ followed by 35 cycles of denaturing at $94^{\circ} \mathrm{C}$ for $1 \mathrm{~min}$, annealing at $52^{\circ} \mathrm{C}$ for 
$1 \mathrm{~min}$ and extension at $72^{\circ} \mathrm{C}$ for $2 \mathrm{~min}$, and a final extension at $72^{\circ} \mathrm{C}$ for $6 \mathrm{~min}$. DNA extract from a 'red plasmodial' parasite (RPP) of copepods, which appears to be one of the closest identified relatives to the genus Ichthyodinium (Skovgaard \& Daugbjerg 2008) served as a negative control. No PCR products from the standard PCR were visible on an ethyl bromine (EtBr)stained agarose gel, and these products were therefore re-amplified in nested PCR. Nested PCR was run under the same conditions as the standard PCR. One $\mu l$ of the products from the standard PCR served as a template for the nested PCR, and the primers used were the Ichthyodinium-specific primers Icth1F, Icht3F, and Icht4R (Table 1). Ichthyodinium-specific primers were designed from known SSU rRNA gene sequences of Ichthyodinium sp. (GenBank accession number AB276368). Specificity of primers was not checked experimentally, but basic local alignment search tool (BLAST) searches yielded only Ichthyodinium as a match for their sequences. PCR product from the negative control of the standard PCR served as template for a negative control in the nested PCR. Final PCR products were purified using NucleoFast ${ }^{\circledR} 96$ PCR plates (Macherey-Nagel).

Sequencing. PCR products were sequenced bidirectionally with an ABI3730xl sequencer (Macrogen) using the external PCR primers and the internal primers ND2F, ND4F, ND7R, and ND9R (Ekelund et al. 2004). Sequence reads were aligned and assembled using the software ChromasPro 1.34 (Technelysium), and their similarities to other known sequences were established by BLAST searches (Altschul et al. 1997).

Survival of infected eggs. In order to monitor the effect of infection on individual cod eggs and larvae, fertilized eggs were incubated and monitored daily for survival, hatching, and possible development of the parasite. The eggs were from eastern Baltic cod that had been collected in 2007 and maintained in the hatchery for 2 yr (repeat spawners). Eggs were kept 4 to $5 \mathrm{~d}$ in incubators before being screened for parasite infection using a stereo microscope, rinsed in $0.2 \mu \mathrm{m}$-filtered artificial seawater, and incubated at $7^{\circ} \mathrm{C}$ in $4 \mathrm{ml}$ Nunc Multidish wells (Thermo Fisher Scientific).

Table 1. Primers designed for amplification of small subunit ribosomal RNA (SSU rRNA) gene of cod endoparasite

\begin{tabular}{lll}
$\begin{array}{l}\text { Primer } \\
\text { Annealing site/ } \\
\text { direction }\end{array}$ & \multicolumn{1}{c}{ Gene sequence $3^{\prime}-5^{\prime}$} \\
\hline Icth1F & SSU/forward & ACTGTGTTGCATACGAACCA \\
Icht3F & SSU/forward & CGGAAGAGCTGCAGTTATTAGA \\
Icht4R & SSU/backward & GGTTTACTAGACTTTCAGCAG
\end{tabular}

\section{RESULTS}

\section{Appearance of endoparasite}

The protistan endoparasite of cod was detected as spheres with diameters of approximately $70 \mu \mathrm{m}$ inside yolk sacs of larvae. It was found both in yolk sacs of embryos inside eggs (Fig. 1A) and in yolk sacs of newly hatched larvae (Fig. 1B). The general appearance of the infection was a single or a few spheres with several internal granule-like structures. At higher magnification, the granule-like structures seemed to be smaller spheres with a diameter of approximately $10 \mu \mathrm{m}$ (Fig. 1C). Some of the spheres exhibited craters on the surface. Smaller spheres were also found outside the large spheres, floating freely in the yolk.

\section{PCR and sequence data}

The standard PCR of parasite samples of 4 infected larvae did not result in any PCR products visible in an agarose gel, and these products were therefore reamplified by nested PCR using Ichthyodinium-specific primers. Two samples (isolates PSO1 and PSO3) yielded nested PCR products that were visible in an agarose gel, and these were then purified and sequenced. No PCR products were ever detected in the negative controls; neither in standard PCR nor in nested PCR. Partial SSU rRNA gene sequences were obtained from the 2 positive samples; 1 of $955 \mathrm{bp}$ length (isolate PS01) and 1 of 1535 bp (isolate PS03). SSU sequences of isolates PSO1 and PSO3 were submitted to GenBank under accession numbers FJ940898 and FJ940899, respectively. The 2 rRNA genes were identical over the length that was sequenced. The 2 sequences were, furthermore, $100 \%$ identical to SSU rRNA gene sequences I. chabelardi of sardine Sardina pilchardus (GenBank accession number FJ440628) and bogue Boops boops (GenBank accession number FJ440624). There was a slight dissimilarity (i.e. $97 \%$ similarity) between $I$. chaberlardi sequences from cod, sardine, and bogue as compared with Asian I. chaberlardi isolates from yellowfin tuna, leopard coral grouper, and Pacific bluefin tuna Thunnus orientalis (GenBank accession numbers AB264776, AB276368, and AB488441, respectively). Attempts were also made to amplify DNA coding for internal transcribed spacers 1 and 2, using the primers of White et al. (1990). These attempts were, unfortunately, unsuccessful. Whether this was due to insufficient template material or because the primer target regions (i.e. SSU, 5.8S, and large subunit [LSU] rRNA) were different from corresponding sequences from Ichthyodinium 


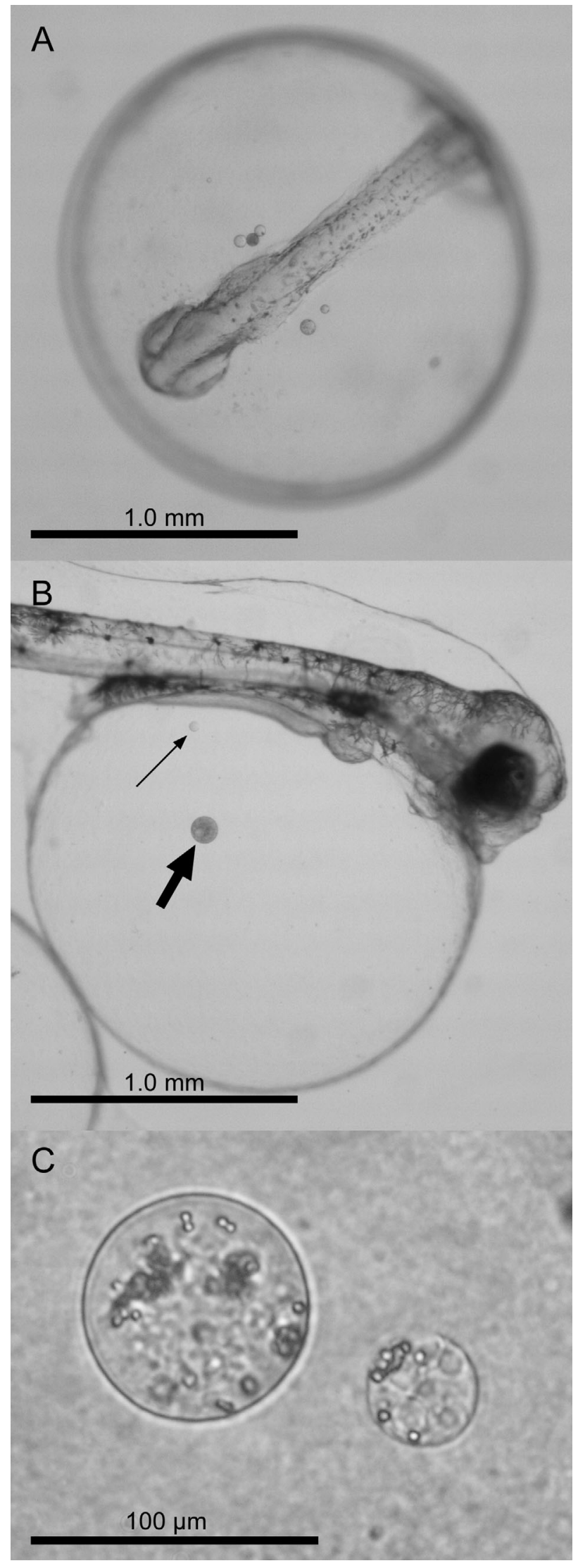

Fig. 1. Ichthyodinium sp. infecting Gadus morhua. (A) Egg of Baltic cod Gadus morhua, in which the embryo is infected with a protistan parasite. The parasite is seen as several spheres of various sizes in the yolk sac of the embryo. (B) Recently hatched Baltic cod larva with 2 spherical parasites in its yolk sac. The upper, smaller sphere (thin arrow) is comparable in size to a vacuole inside the lower, larger sphere (thick arrow). (C) Two differently sized parasite spheres inside the yolk sac of a Baltic cod larva

sp., which served as basis for the design of primers, is currently unknown.

\section{Survival of infected eggs}

The incubation of infected, fertilized eggs revealed no parasite-induced mortality (Fig. 2). On the contrary, infected eggs had a hatching success that was similar to that of uninfected eggs, and the hatched larvae exhibited similar short-term mortality. Daily inspections of eggs did not reveal any increase in parasite cell mass; the infection was thus only ever evident in the form of a few spherical cells in the yolk sacs of eggs and larvae. The presence of parasite cells in larval tissue other than the yolk sac was not examined.

\section{DISCUSSION}

It may not seem surprising that the endoparasite of cod eggs and larvae has a partial SSU rRNA gene identical to that of Ichthyodinium chabelardi, given that

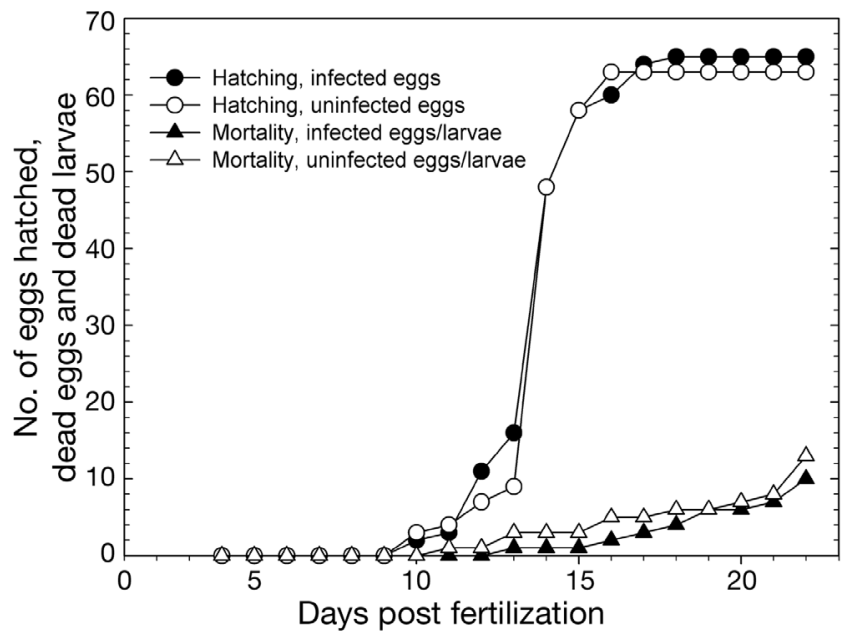

Fig. 2. Ichthyodinium sp. infecting Gadus morhua. Hatching (circles) and mortality (triangles) of cod Gadus morhua eggs infected with an endoparasitic protist $(\mathrm{n}=72$; closed symbols) and uninfected eggs ( $\mathrm{n}=72$; open symbols). The fertilized eggs were isolated and incubated individually in $4 \mathrm{ml}$ of artificial seawater $\left(7^{\circ} \mathrm{C}\right.$, salinity $\left.16 \mathrm{psu}\right)$ 
several authors have already suggested that the endoparasite of cod might be a species of this genus. However, a close similarity between these 2 organisms was not fully evident in previous studies. There is an obvious similarity in the strategy of infection of the 2 organisms, since they are both present in yolk sacs of fish larvae. In addition, I. chaberlardi and the cod endoparasite share some morphological traits: (1) they both produce spherical, mononucleate stages that develop into plasmodial multinucleate stages (Hollande \& Cachon 1952, Pedersen et al. 1993); (2) their mononucleate stages are in the same size range; and (3) at the ultrastructural level both have mitochondria with tubular cristae (Pedersen et al. 1993, Gestal et al. 2006).

Major dissimilarities between the endoparasite of cod and Ichthyodinium chaberlardi are the aggressiveness of infection, the apparent lack of flagellated swarmer cells in the cod parasite, and the size and numbers of vacuoles in the cytoplasm of parasite cells (Pedersen \& Køie 1994). Another trait that seemingly distinguishes the parasite of cod and turbot from $I$. chaberlardi in other fish species is the fact that cells of the cod parasite invade the host tissue and bloodstream, and parasite cells have even been found in the beating heart of a cod larva (Pedersen \& Køie 1994, Bloch et al. 1997). On the other hand, in all other cases of $I$. chaberlardi infection, parasite cells have only been found in the yolk sacs of the host. There also seem to be differences at the ultrastructural level, even though ultrastructural studies on the endoparasite of cod have revealed remarkably few characteristic traits (Pedersen et al. 1993, Pedersen \& Køie 1994, Bloch et al. 1997): I. chabelardi has trichocysts (Gestal et al. 2006), which appear to be absent from cod endoparasite (Pedersen et al. 1993, Bloch et al. 1997). However, the presence and number of trichocysts may not be constant but appear to be dependent on the developmental stage of the parasite cell (Gestal et al. 2006). Bloch et al. (1997) observed annulate lamellae and intra- and extracellular, nucleated 'elements' that could represent the above-mentioned daughter cells. The latter study did not comment on any apparent similarity to $I$. chabelardi.

Just as might be the case with the trichocysts, it is also possible that the differences that have been observed between numbers and sizes of cytoplasmic vacuoles of Ichthyodinium chabelardi and the endoparasite of cod and turbot are a result of the different developmental stages observed in the various studies. The cod parasite cell is reported to contain several small vacuoles (Pedersen et al. 1993), whereas I. chabelardi in sardine has 1 very large cytoplasmic vacuole (Hollande \& Cachon 1952). However, more recent data suggest that the number of vacuoles in I. chabelardi cells depends on the developmental stage (Gestal et al. 2006), ranging from 1 large to several smaller vacuoles.

Ichthyodinium chaberlardi causes more aggressive infections than the cod endoparasite. This aggressiveness is linked to the rapid growth and the production of flagellated swarmer cells that results in rupture of the yolk sac. Swarmer cells have never been observed for the cod endoparasite, either in cod or in turbot. On the other hand, all observations of $I$. chaberlardi in various fish species report a massive and consistent production of motile swarmers, and it is the morphology of these which is the main reason why $I$. chaberlardi is traditionally classified as a dinoflagellate. In this respect, it is interesting that Pedersen \& Køie (1994) observed a single intracellular flagellum in the endoparasite in turbot. Such intracellular flagella were also observed by Gestal et al. (2006) in multinucleate cells, which were presumably in the process of producing swarmer cells. It thus seems that the endoparasite of cod and turbot has the potential to produce flagellated cells (swarmers), but for some reason this swarmer production is hindered. At least, if swarmers are produced in the endoparasite in cod and turbot they are not produced or observed as readily as in the case of $I$. chabelardi in sardine, mackerel, and yellowfin tuna.

Hence, the ultrastructural differences between Ichthyodinium chabelardi and the cod endoparasite may not represent actual differences, since they appear to vary with developmental stage. There does, on the other hand, seem to be a clear difference in the parasites' potential of rapid proliferation, which in turn leads to different schemes of aggressiveness: I. chabelardi kills its host within a few days after infection, whereas the cod endoparasite can persist in its host for several days without any experimentally proven effects on the host. In the present study, no effect of the parasite infection could be documented (Fig. 2), and parasite cells did not seem to proliferate. One can only speculate why I. chabelardi and the cod endoparasite, which are seemingly closely related and perhaps the same genus or species, vary in virulence. One explanation could be that cod and turbot are not suitable hosts for the development of the parasite, and that the parasite therefore cannot proliferate and produce swarmers. It is also possible that the salinity or temperature of the Baltic Sea is not suitable for proliferation of $I$. chaberlardi. All reports on the production of I. chaberlardi swarmers and the high egg and larval mortalities associated with this sporulation are from warmer temperate or tropical waters of full strength ocean salinity (Hollande \& Cachon 1952, 1953, Stratoudakis et al. 2000, Meneses et al. 2003, Mori et al. 2007, Yuasa et al. 2007). The endoparasite in both cod and turbot was, on the other hand, sampled in the environment of a cold temperate estuary, with temperature and salinity rang- 
ing from 5 to $16^{\circ} \mathrm{C}$ and 16 to 22 psu, respectively (Buchmann et al. 1993, Pedersen 1993, Pedersen et al. 1993). In a single study, cod eggs were incubated at higher salinity $\left(31 \mathrm{psu}\right.$ and 6 to $8^{\circ} \mathrm{C}$; Pedersen \& Køie 1994), but no parasite swarmer production was observed in this case either. However, considering that the endoparasite is common in both cod and turbot and has been observed in the Baltic Sea on many occasions (Buchmann et al. 1993, Pedersen 1993, Pedersen et al. 1993, Pedersen \& Køie 1994), it seems unlikely that the physical environment in the Baltic Sea should be unsuitable for the completion of the parasite's life cycle.

Similarity between 2 SSU rRNA gene sequences, or at least similarity between the major part of 2 sequences as shown here for the cod endoparasite and Ichthyodinium chabelardi, does not itself prove that the sequences originate from a single species. One issue is that the thus far unknown part of the cod endoparasite SSU rRNA gene could be divergent from that of I. chabelardi; it is also possible that the cod endoparasite and $I$. chabelardi have identical SSU rRNA genes but exhibit other genetic and morphological differences that warrant their classification as 2 different species. Even though such a scenario is uncommon, it has recently been described for 2 free-living, phototrophic dinoflagellates (Logares et al. 2007). In summary, the exact match of the partial SSU rRNA gene sequences of the cod endoparasite and I. chabelardi may not prove definitively that the 2 parasites are a single species, but it is likely that this is the case. In any case, it is certain that the 2 parasites are very closely related.

Ichthyodinium chabelardi has traditionally been classified as a dinoflagellate of the order Syndiniales (Hollande \& Cachon 1952). More recent analyses based on molecular phylogeny show that Syndiniales are not typical dinoflagellates but instead constitute a sister group to these (Skovgaard et al. 2005). However, the grouping of Ichthyodinium within Syndiniales may also be incorrect, since it is associated with a second sister group to the typical dinoflagellates, the so-called marine alveolate Group I (Skovgaard et al. 2009). Hence, 3 genetically distinct groups of dinoflagellatelike organisms seem to exist, even though the exact relationship between these groups is still a matter of debate (Guillou et al. 2008).

Acknowledgements. This work was supported through a grant from the Villum Kann Rasmussen Foundation. Baltic eggs and larvae were obtained through the RESTOCK project ('Improving Eastern Baltic cod stocks through restocking') funded by the EU and Danish Ministry of Food, Agriculture, and Fisheries through the EU Financial Instrument for Fisheries Guidance (FIFG). The authors thank Céline Marochin, University of Caen, France, for help with egg incubation and monitoring and the isolation of endoparasite material.

\section{LITERATURE CITED}

Altschul SF, Madden TL, Schäffer AA, Zhang J, Zhang Z, Miller W, Lipman DL (1997) Gapped BLAST and PSIBLAST: a new generation of protein database search programs. Nucleic Acids Res 25:3389-3402

Bloch B, Pedersen BH, Jensen PV (1997) An enigmatic and possible parasitic organism in the tissues of embryonated eggs of Baltic cod Gadus morhua. Dis Aquat Org 30: 121-135

> Buchmann K, Larsen JL, Dalsgaard I (1993) Diseases and injuries associated with mortality of hatchery reared Baltic cod (Gadus morhua) larvae. Acta Vet Scand 34:385-390

> Ekelund F, Daugbjerg N, Fredslund K (2004) Phylogeny of Heteromita, Cercomonas and Thaumatomonas based on SSU rDNA sequences, including the description of $\mathrm{Neo}$ cercomonas jutlandica sp. nov., gen. nov. Eur J Protistol 40:119-135

Gestal C, Novoa B, Posada D, Figueras A, Azevedo C (2006) Perkinsoide chabelardi n. gen., a protozoan parasite with an intermediate evolutionary position: possible cause of the decrease of sardine fisheries? Environ Microbiol 8: $1105-1114$

Guillou L, Viprey M, Chambouvet A, Welsh RM and others (2008) Widespread occurrence and genetic diversity of marine parasitoids belonging to Syndiniales (Alveolata). Environ Microbiol 10:3349-3365

Hollande A, Cachon J (1952) Un parasite des oeufs de sardine: l'Ichthyodinium chabelardi nov. gen. nov. sp. (Péridinien parasite). C R Acad Sci Paris 235:976-977

Hollande A, Cachon J (1953) Morphologie et évolution d'un Péridinien parasite des oeufs de sardine (Ichthyodinium chabelardi). Bull Trav Stat Aquic Pech Castiglione 4: 321-331

Logares R, Rengefors K, Kremp A, Shalchian-Tabrizi K and others (2007) Phenotypically different microalgal morphospecies with identical ribosomal DNA: A case of rapid adaptive evolution? Microb Ecol 53:549-561

Marinaro JY (1971) Contribution à l'étude des oeufs et larves pélagiques de poissons méditerranéens. V. Oeufs pélagiques de la Baie d'Alger. Pelagos 3:1-118

Medlin L, Elwood HJ, Stickel S, Sogin ML (1988) The characterization of enzymatically amplified eukaryotic 16S-like rRNA-coding regions. Gene 71:491-499

Meneses I, Vendrell C, Stratoudakis Y (2003) Mackerel (Scomber scombrus) eggs parasitized by Ichthyodinium chabelardi in the north-east Atlantic: an overlooked source of mortality. J Plankton Res 25:1177-1181

Mori K, Yamamoto K, Teruya K, Shiozawa S and others (2007) Endoparasitic dinoflagellate of the genus Ichthyodinium infecting fertilized eggs and hatched larvae observed in the seed production of leopard coral grouper Plectropomus leopardus. Fish Pathol 42:49-57

> Pedersen BH (1993) Embryos and yolk-sac larvae of turbot Scophthalmus maximus are infested with an endoparasite from the gastrula stage onwards. Dis Aquat Org 17: 57-59

> Pedersen BH, Køie M (1994) A protistan endoparasite in embryos and yolk-sac larvae of cod Gadus morhua and turbot Scophthalmus maximus. Dis Aquat Org 19:39-46

> Pedersen BH, Buchmann K, Køie M (1993) Baltic larval cod Gadus morhua are infested with a protistan endoparasite in the yolk sac. Dis Aquat Org 16:29-33

> Skovgaard A, Daugbjerg N (2008) Identity and systematic position of Paradinium poucheti and other Paradiniumlike parasites of marine copepods based on morphology and nuclear-encoded SSU rDNA. Protist 159:401-413 
Skovgaard A, Massana R, Balagué V, Saiz E (2005) Phylogenetic position of the copepod-infesting parasite Syndinium turbo (Dinoflagellata, Syndinea). Protist 156: 413-423

Skovgaard A, Meneses I, Angélico MM (2009) Identifying the lethal fish egg parasite Ichthyodinium chabelardi as a member of marine alveolate Group I. Environ Microbiol 11:2030-2041

Støttrup JG, Overton JL, Paulsen H, Möllmann C, Tomkiewicz J, Pedersen PB, Lauesen P (2008) Rationale for restocking the eastern Baltic cod stock. Rev Fish Sci 16: $58-64$

Editorial responsibility: David Marcogliese, Montreal, Quebec, Canada
Stratoudakis Y, Barbosa A, Meneses I (2000) Infection of sardine eggs by the protistan endoparasite Ichthyodinium chabelardi off Portugal. J Fish Biol 57:476-482

White TJ, Bruns T, Lee S, Taylor J (1990) Amplification and direct sequencing of fungal ribosomal RNA genes for phylogenetics. In: Innis MA, Gelfand DH, Sninsky JJ, White TJ (eds) PCR protocols: a guide to methods and applications. Academic Press, New York, p 315-322

Yuasa K, Kamaishi T, Mori K, Hutapea JH, Permana IGN, Nakazawa A (2007) Infection by a protozoan endoparasite of the genus Ichthyodinium in embryos and yolk-sac larvae of yellowfin tuna Thunnus albacares. Fish Pathol 42:59-66

Submitted: May 12, 2009; Accepted: September 23, 2009 Proofs received from author(s): January 11, 2010 